\title{
Urgensi Quantum Ikhlas untuk Kesehatan Mental di Masa Pandemi Covid-19
}

\author{
Nurhalimah \\ Universitas Islam Negeri (UIN) Sunan Ampel Surabaya \\ halimahnur504@gmail.com \\ Agus Aditoni \\ Universitas Islam Negeri (UIN) Sunan Ampel Surabaya \\ agusaditoni@uinsby.ac.id
}

\begin{abstract}
This article aims to find out the urgency of quantum ikhlas to achieve mental health amid the uncertainty of the end of Covid-19. Quantum ikhlas is the integration between ikhlas and knowledge. Quantum is something that is not invisible, but the more subtle it is, the greater its power. During the Covid-19 pandemic, health challenges are the main target, both physically and mentally. Likewise with mental health, where during the pandemic the cases are getting bigger. In this position, religion has provided a solution. One of them is by teaching ikhlas in accepting all the provisions that Allah has given. Even though in reality today's society often grumbles and blames the situation. No wonder this attitude makes him even more disappointed, frustrated, stressed and depressed. This study uses descriptive qualitative research, type of literature. By collecting all sources, both page articles, journals, and books. Only then analyzed. The results of this study, quantum ikhlas has an urgency to achieve mental health in the face of a pandemic. Because with ikhlas, someone will accept the situation and bring peace within him.
\end{abstract}

Keywords: Quantum ikhlas; mental health; covid-19

\begin{abstract}
Abstrak
Artikel ini bertujuan untuk mengetahui urgensi quantum ikhlas untuk meraih kesehatan mental di tengah ketidakpastian berakhirnya Covid-19. Quantum ikhlas merupakan integrasi antara ikhlas dengan ilmu pengetahuan. Quantum adalah sesuatu yang tidak terlihat, tetapi semakin
\end{abstract}


halus maka kekuatannya semakin besar. Di masa pandemi Covid 19 tantangan dalam kesehatan menjadi sasaran utama, baik fisik dan jiwa. Begitu pun dengan kesehatan mental, di mana selama pandemi kasusnya semakin besar. Posisi inilah agama sejatinya telah memberikan solusi. Salah satunya dengan mengajarkan keikhlasan dalam menerima segala ketentuan yang Allah berikan. Meski pada realitanya masyarakat hari ini kerapkali menggerutu dan menyalahkan keadaan. Tidak heran dengan sikap begitu menjadikannya semakin kecewa, frustasi, stres dan depresi. Mendedah ini menggunakan penelitian kualitatif deskriptif, jenis pustaka. Dengan cara mengumpulkan seluruh sumber baik artikel laman, jurnal, hingga buku. Baru kemudian dianalasis. Hasil dari penelitian ini, quantum ikhlas memiliki urgensi untuk meraih kesehatan mental dalam menghadapi pandemi. Karena dengan ikhlas, seseorang akan menerima keadaan dan membawa kedamaian dalam dirinya.

Kata Kunci: Quantum ikhlas; kesehatan mental; covid-19

\section{Pendahuluan}

Perasaan dihantui terus menerus mengintai masyarakat di dunia. Perihal kedatangan virus bernama Corona Virus Disease 19 (Covid-19). Berawal dari Wuhan, kemudian merebak ke seluruh dunia, tidak terkecuali dengan Indonesia. Beragam kasus kematian terus bertambah akibat dari virus tidak terlihat itu. Semakin membuat masyarakat ketakutan, meski nyatanya yang menyepelekan pun tidak sedikit.

Pertama kali masuk ke Indonesia, pemberitaan mengenai virus ini begitu getol diperbincangkan. Hampir keseluruhan saluran televisi menampilkan data korban, ditambah lagi dengan laman-laman website pemberitaan dan video di media digital, terlihat memperkeruh keadaan. Sampai-sampai tenaga kesehatan, orang yang terinfeksi beserta keluarganya, diperlakukan tidak manusiawi oleh masyarakat sekitarnya. Karena khawatir akan tertular Covid-19. Seperti kasus yang terjadi di Sulawesi Selatan pada 1 April 2020 tahun lalu. Jenazah pasien yang terpapar Covid ditunda penguburannya dikarenakan warga sekitar menolak jenazah. Pasalnya ambulan yang membawa korban ditolak secara paksa dan keluarga yang meninggal diusir oleh warga setempat. ${ }^{1}$

Hingga detik ini, kasus ketakutan dan kekhawatiran akan virus Covid merajalela di kalangan masyarakat. Tidak jarang menggerutu, menyalahkan pihak pemerintah dan tenaga kesehatan, serta menganggap kejadian Covid itu rekaan belaka. Sikap curiga mencurigai bukan hanya bertebaran di lingkungan sekitar, di

\footnotetext{
1 Tri Purna Jaya, "Sederet Kasus Warga Tolak Pemakaman Jenazah Pasien Covid-19 di Berbagai Daerah,” kompas.com, 2020, https://regional.kompas.com/read/ 2020/04/01/05200021/sederet-kasus-warga-tolak-pemakaman-jenazah-pasien-covid-19-diberbagai.
} 
media sosial pun bertebaran narasi semacam itu. Hoax semakin merajalela, beberapa oknum mengambil kesempatan agar masyarakat tidak percaya akan adanya virus itu. Meski telah diperintahkan untuk beribadah di rumah, menjaga jarak, dan taat pada protokol kesehatan, tetapi tetap saja dilanggar.

Akibat kedatangan Covid banyak tenaga kerja yang di PHK dan juga tidak sedikit perusahaan gulung tikar. Juga menjadi bahan ketidakterimaan di dalam hati masyarakat. Sekolah yang dialihkan ke daring dan rendahnya ekonomi menjadi bagian dari alasan menggerutu di masyarakat. Tidak jarang orang tua siswa mengalami gangguan dalam kesehatan mental, sehingga melampiaskan pada anak-anaknya di rumah. ${ }^{2}$ Kerapkali ditemui para netizen menyalahkan presiden, tenaga kesehatan. Bahkan berani menyalahkan Tuhan, seakan lupa bahwa terlahirnya ke dunia memang ditakdirkan dengan beragam tantangan. Sebagai khalifah di bumi seharusnya menyadari akan konsekuensi menjadi wakil Tuhan di dunia

Indonesia dengan mayoritas masyarakat beragama, pasti diajarkan rasa akan keikhlasan, serta kesabaran dalam menghadapi pandemi. Di dalam Islam pun Allah berfirman dalam Alquran agar mengambil hikmah dari segala kejadian. Memang persoalan tentang wabah Covid-19 tidak jarang umat beragama menanggalkan rasionalitasnya, untuk memuaskan perasaannya dengan tetap melaksanakan ibadah di tempat ibadah meskipun ada perintah PSBB (Pembatasan Sosial Berskala besar). Seperti hasil penelitian sebuah jurnal yakni sikap keberagamaan umat muslim masih saja melakukan ibadah di masjid meski ada pembatasan skala besar-besaran. ${ }^{3}$

Dilansir dari laman tirto.id, Direktur Jenderal WHO (World Health Organization) yakni Tedros Adhanom Ghebreyesus pada tanggal 9 Oktober 2020 lalu, menyiarkan secara resmi. Bahwa pandemi telah memberikan dampak begitu besar terhadap kesehatan mental jutaan orang. Bukan hanya tenaga kesehatan, tetapi pelajar dan pendidik yang tidak bisa sekolah secara langsung, para pekerja pun rentan terpapar virus dan PHK. Banyak masyarakat yang jatuh miskin, hingga persoalan isolasi mandiri, vaksinasi, memberikan sumbangsih mental illness sebagai lawan dari kesehatan mental. ${ }^{4}$ Perasaan khawatir, takut, semakin menghantui. Apalagi ditambah dengan adanya PPKM (Pemberlakuan Pembatasan Kegiatan Masyarakat) yang sudah berlangsung sejak 3 Juli 2021. Hal

2 Ainun Mustarsyida and Erni Munastiwi, "Problematika Orang Tua Dalam Mendampingi Anak Pada Pembelajaran Era Pandemi Covid-19," Islamic Counseling: Jurnal Bimbingan Dan Konseling Islam 5, no. 1 (2021): 10, http://journal.iaincurup.ac.id/index.php/JBK.

3 Dadang Darmawan et al., "Sikap Keberagamaan Masyarakat Menghadapi Wabah COVID-19," Religious: Jurnal Studi Agama-Agama Dan Lintas Budaya 4, no. 2 (2020): 115-24, https://doi.org/10.15575/rjsalb.v4i2.8596.

4 Ayub Rustiani, "Data Riset: Kesehatan Mental Mahasiswa Saat Pandemi \& Kuliah Online," tirto.id, 2021, https://tirto.id/data-riset-kesehatan-mental-mahasiswa-saat-pandemikuliah-online-gaEc. 
ini dilakukan sebagai salah satu ikhtiar pemerintah yang dilatarbelakangi atas meledaknya korban Covid-19. Banyak rumah sakit penuh dan para korban yang harus mengantri untuk menggunakan ambulan. Narasi pada Rabu, 7 Juli 2021 Najwa Shihab menghadirkan kisah salah satu masyarakat yang anggota keluarganya meninggal karena Covid. Menurut dia merasa tidak wajar, tidak bisa mengelus anggota keluarganya dan tidak bisa memandikan jenazah saudaranya sebagai penghormatan terakhir. Perasaan semacam ini pasti banyak orang yang mengalami. Tidak bisa melepaskan ke tempat peristirahatan orang tersayang. Alhasil perasaan tidak bermakna, hampa, kecewa, menjadi hantu dalam pikiran.

S. Winarni dalam artikelnya Permasalahan Kesehatan Mental Akibat Covid-19 menyebutkan, di masa pandemi ini banyak orang yang mengalami persoalan kesehatan mental. Persoalan ini terjadi, tidak lain karena Covid 19 adalah sumber stres baru bagi masyarakat. Setidaknya disebabkan; jarak dan isolasi sosial sehingga menyebabkan ketakutan serta tekanan emosional. Merasa terasing sebab tidak seperti biasanya. Sehingga mental menjadi sasarannya. Kasus yang nyata terjadi di Arab Saudi, seorang mahasiswa asal Cina nekat bunuh diri akibat isolasi mandiri karena positif. Kemudian karena resesi ekonomi, stres, dan trauma pada penyakit, serta stigma atau diskriminasi di masyarakat akibat terinfeksi Covid 19. ${ }^{5}$ Namun artikel yang diterbitkan oleh Bidang Kesejahteraan Sosial, Penelitian Keahlian DPR RI ini, tidak memberikan solusi. Hanya sebatas penyebutan permasalahan kesehatan mental akibat pandemi.

Selaras pula dengan jurnal yang ditulis Salma Matla Ilpaj dan Nunung Nurwati, Pengaruh Tingkat Kematian Akibat Covid-19 Terhadap Kesehatan Mental Masyarakat di Indonesia, yang terbit pada tahun 2020. Salah satu bagian yang menyebabkan kesehatan mental terganggu karena terjadi penambahan kematian terus menerus. Jurnal ini pun memberikan solusi dengan melalukan kegiatan fisik positif. Padahal disamping aktivitas fisik seperti makan makanan bergizi, menjalin relasi baik dengan keluarga, atau berolahraga. Ada satu hal yang harus diupayakan yakni ajaran agama. Akan tetapi jurnal ini tidak menyebutkannya. ${ }^{6}$

Masih sejalan dengan penelitian yang diterbitkan Jurnal Praxis pada September 2020. Tulisan Muhammad Iqbal dan Lutfiyah Rizqulloh, dengan judul Deteksi Dini Kesehatan Mental Akibat Pandemi Cobid-19 Pada Unnes Sex Care Community Melalui Metode Self Reporting Questionnaire. Penelitian yang menggunakan kuantitatif deskriptif dengan pengambilan sampel di kalangan Mahasiswa Unnes sebanyak 44 responden. Data yang dihasilkan setidaknya 63,6\% responden mengalami problem kesehatan secara mental, 26 dari 44 responden atau 59\%

\footnotetext{
5 Sulis Winurini, "Permasalahan Kesehatan Mental Akibat Pandemi COVID-19," Info Singkat: Kajian Singkat Terhadap Isu Aktual Dan Strategis, 2020.

'Salma Matla Ilpaj and Nunung Nurwati, "Analisis Pengaruh Tingkat Kematian Akibat Covid-19 Terhadap Kesehatan Mental Masyarakat Di Indonesia," Focus : Jurnal Pekerjaan Sosial, 2020, 26, https://doi.org/10.24198/focus.v3i1.28123.
} 
mengalami perasaan tegang, cemas, dan khawatir selama 30 hari ke bealakang. Kemudian $50 \%$ dari responden sukar tidur selama 30 hari terakhir, 50\% dari responden menyebutkan sulit berfikir jernih, 22 orang dari responden ini mengalami kelelahan sepanjang 30 hari, dan 9\% dari responden memiliki pemikiran untuk mengakhiri hidup. Dari penelitian ini betapa begitu terlihat bahwa sepenuhnya Covid-19 mengganggu kesehatan mental terkhusus mahasiswa. Data yang disebut terlihat keseluruhan responden mengalami kesehatan mental rendah. ${ }^{7}$ Islam sebagai agama yang lengkap, sebetulnya telah memberikan solusi dalam kesehatan mental. Salah satunya melalui quantum ikhlas, akan tetapi tidak banyak yang mengkaji mengenai hal ini. Padahal melihat problem yang dihadapi oleh masyarakat saat ini, ikhlas mulai terabaikan ketika keadaan sudah tidak lagi seperti yang dibayangkan. Ketidakpastiaan belum tahu kapan ujungnya. Disinilah alasan terbesar menjadikan Quantum Ikhlas sebagai solusi mendapatkan kesehatan mental di tengah pandemi Covid-19.

Pertimbangan lainnya, mengenai penelitian Quantum Ikhlas untuk kesehatan mental jarang ditemui. Meski penelitian terbaru 2021 tentang terapi realitas menggunakan nilai-nilai ikhlas menghasilkan, bahwa dengan modal ikhlas memberikan pengaruh kepada pengantin yang gagal menikah. Sehingga pengantin ini berhasil menerima realita dengan memilih akad saja, dibandingkan membuat acara syukuran yang besar. ${ }^{8}$ Pada nyatanya penelitian dalam skripsi ini tidak mengaitkan ikhlas dengan kesehatan mental, hanya cukup pada sisi penerimaan realitas saja. Berangkat dari beberapa penelitian sebelumnya dan realita pandemi Covid-19 yang mengganggu kesehatan mental, di sinilah tulisan ini berniat membahas sejauh manakah urgensi quantum ikhlas untuk dijadikan solusi dalam meraih kesehatan mental pandemi.

\section{Hasil dan Pembahasan}

\section{Definisi Sehat}

Bicara sehat akhir-akhir ini sangat berharga. Ketika menyaksikan pemberitaan, tetangga, maupun keluarga banyak yang sakit. Benar ucapan pepatah, sehat itu mahal. Namun sayangnya sebagian manusia lebih memilih "menyembuhkan" ketika sakit, dibandingkan mencegah sebelum sakit. Sehat dalam Kamus Besar Bahasa Indonesia berarti baik seluruh badannya,

7 Muhammad Iqbal and Lutfiyah Rizqulloh, "Deteksi Dini Kesehatan Mental Akibat Pandemi Covid-19 Pada Unnes Sex Care Community Melalui Metode Self Reporting Questionnaire," Praxis 3, no. 1 (2020): 24, https://doi.org/10.24167/praxis.v3i1.2730.

8 Rizky Claravita, "Akan Gagalnya Resepsi Karena Pandemi Covid-19 Pada Pasangan Calon Pengantin Di Kelurahan Morokrembangan Surabaya" (UIN Sunan Ampel Surabaya, 2020), iv. 
mendatangkan kebaikan pada badan, sembuh dari sakit, baik dalam pikiran, berjalan dengan baik, dan lain sebagainya. ${ }^{9}$

Undang undang nomor 23 Tahun 1992 menyebut kesehatan ialah sebuah keadaan sejahtera baik badan, jiwa, maupun sosial. Sehingga dapat membuat seseorang produktif secara sosial maupun ekonomi. Berangkat dari inilah Kementerian Kesehatan menyebut manusia ditilik sebagai sesuatu yang holistik dari unsur badan, jiwa, maupun sosial. Hal ini bukan sekadar persoalan penyakit, tetapi kualitas hidup juga berperan. Mengenai definisi yang disebutkan dalam UU kesehatan jiwa, merupakan sisi mata koin yang tidak lagi bisa dipisahkan. Kesehatan merupakan komponen utama, bahkan tidak berlebihan jika dikatakan kendali utama untuk terwujudnya hidup manusia sepenuhnya. Ciri-ciri orang yang sehat jiwanya ialah ketika merasa senang terhadap dirinya sendiri, memiliki rasa nyaman dengan orang lain, dan mampu memenuhi tuntutan hidupnya. Disamping itu mampu menghadapi segala situasi yang dihadapi, mampu mengendalikan kekecewaan dalam hidupnya, merasa puas dengan kehidupan kesehariannya, memiliki harga diri yang wajar, dan mampu menilai dirinya secara realistis, tidak berlebihan, serta tidak merendahkan. ${ }^{10}$

Selarasa dengan penjelasan WHO yang dimaksud sehat; adanya keseimbangan antara fisik, mental, dan sosial. Bukan sekadar terbebas dari sakit. Dengan demikian seseorang yang sehat secara fisik, belum tentu bisa disebut sehat secara keseluruhan, akan tetapi komponen tubuh lainnya juga perlu sehat. Disederhanakan lagi menjadi biologis, psikologis, serta sosial. Biologis artinya WHO menjadikan manusia sebagai perhatiannya. Secara psikologis melihat sehat dari lingkungan internal maupun eksternalnya. Sedangkan sosial diartikan sebagai hidup yang penuh kreativitas dan produktif. Sehat termasuk ke dalam bagian mampu menyesuaikan, tetapi sehat tidak diartikan sebagai keadaan. Akan tetapi sebagai adaptasi seorang individu dengan menyeimbangkan tiga komponen itu. ${ }^{11}$

Sehat secara fisik artinya semua anggota tubuh normal, kemudian sehat pikiran teraktualisasi dalam berperilaku, dan terakhir sehat spiritual merepresentasikan rasa syukur. Sehat secara emosional artinya mampu melihat dirinya dan mengendalikan dirinya, serta sehat dalam ekonomi. Semuanya harus berkelindan untuk bisa dikatakan sehat. ${ }^{12}$ Disamping sehat secara fisik dan jiwa, WHO juga memberikan definisi terkait kesehatan mental. Di mana ada satu hari yang dijadikan untuk memperingati kesehatan mental. Badan Kesehatan Dunia

9 Kementerian Pendidikan dan Kebudayaan Indonesia, "KBBI V" (Badan Pengembangan Bahasa dan Perbukuan, 2020).

${ }^{10}$ Kementerian Kesehatan, "Sehat Jiwa," kemkes.go.id, accessed July 9, 2021, https://promkes.kemkes.go.id/content/?p=7385.

${ }^{11}$ Nadya, "Konsep Sehat Dan Sakit," uin-alauddin.ac.id, 2013, https://uinalauddin.ac.id/tulisan/detail/konsep-sehat-dan-sakit.

12 Nadya. 
menyebut kesehatan mental ialah kemampuan adaptasi seseorang, baik dengan dirinya sendiri maupun lingkungan sekitarnya. Sehingga orang itu merasa bahagia dan pasti senang. ${ }^{13}$

Kesehatan mental berkelindan dengan adaptasi kognitif, perasaan, serta emosional. Seseorang yang mengalami gangguan kesehatan mental ia akan stres, depresi, dan kecemasan berlebihan sehingga mengganggu aktivitas kesehariannya. ${ }^{14}$ Semua komponen kesehatan di atas begitu penting. Tidaklah betul ketika mendapati perkataan badan yang sehat disitulah ada jiwa yang sehat. Sebab sehat fisik saja-misalnya—tidak berarti mewakili keseluruhan. Semuanya harus saling berpegang tangan, baik fisik, jiwa, dan tentunya mental.

\section{Indikator Kesehatan Mental}

Kesehatan mental atau mental bealth atau mental bygiene, dilihat dari sejarahnya merupakan pecahan dari psikologi. Usaha yang dilakukan oleh psikologi disebabkan banyaknya keluhan dari masyarakat. Dengan gejala kegelisahan dan tidak hanya dirasakan oleh satu individu saja, tetapi seluruh masyarakat. Ketika berada di tataran ringan masih bisa ditangani sendiri, akan tetapi ketika besar maka penyandangnya sukar menanganinya. Fenomena itu bukan hanya mengganggu dirinya sendiri tetapi lingkungan sekitarnya. ${ }^{15}$ Secara umum para psikolog menyepakati kesehatan mental sebagai sebuah kematangan emosional sekaligus sosial sebagai bahan beradaptasi dengan lingkungan. Termasuk kemampuan dalam memegang tanggungjawab serta menghadapi segala persoalan di muka bumi. Sehingga seseorang akan merasa tenang dan bahagia dalam menjalankan tugasnya sebagai khalifah di muka bumi. ${ }^{16}$

Memperbincangkan kesehatan mental menurut Zakiah Daradjat kedudukannya simultan dengan gangguan dan penyakit kejiwaan. Akan tetapi pengertian ini cenderung klasik yang memahami secara terbatas pada mereka yang mengalami gangguan saja. Padahal kehadiran kesehatan mental memiliki kebermanfaatan untuk seluruh manusia dalam meraih hidup tentram serta bahagia. ${ }^{17}$

Zakiah Daradjat menyuguhkan empat indikator seseorang dapat meraih kesehatan mental; yakni ketika seseorang itu mampu mengendalikan diri dari gangguan mental atau disebut neuroses dan psikose atau penyakit, di saat seseorang

${ }^{13}$ Muhammad 'Utsman Najati, Al-Hadits an-Nabawi Wa 'Ilm an-Nafs (Bandung: Pustaka Hidayah, 2005), 323.

${ }^{14}$ Retia Kartika Dewi, "Hari Kesehatan Mental Sedunia: Apa Itu Kesehatan Mental Dan

Bagaimana Cara Menjaganya," kompas.com, accessed July 10, 2021, https://www.kompas.com/tren/read/2020/10/10/171200265/hari-kesehatan-mental-seduniaapa-itu-kesehatan-mental-dan-cara-menjaganya.

15 Zakiah Daradjat, Kesehatan Mental (Jakarta: Haji Masagung, 1990), 10.

${ }^{16}$ Najati, Al-Hadits an-Nabawi Wa 'Ilm an-Nafs, 9.

${ }^{17}$ Najati, 85. 
mampu menjalin hubungan antara hubungan baik secara horizontal maupun vertikal, kemudian mampu mengendalikan segala masalah dalam kehidupannya, serta terciptanya keharmoniasan dan keserasian fungsi kejiwaan. Menyitir bahasa Daradjat kesehatan mental sebagai kondisi kejiwaan seseorang. Dengannya kesehatan mental seseorang dapat diukur. Semakin banyak yang tidak terpenuhi dari empat indikator, maka semakin rendah kesehatan mental seseorang itu. ${ }^{18}$

Sedangkan Abraham Maslow sebagai psikolog humanistik teori legendarisnya, hirarki kebutuhan. Menyebut indikator kesehatan mental ketika seseorang mampu berhubungan dengan dirinya sendiri seperti bersikap jujur kepada dirinya atau kepada orang lain, berani dalam mengungkapkan kebenaran, berani mengakui apa yang diinginkan, berani mengakui hal baik yang tidak berasal dari dirinya sendiri, dan menerima segala hal baik serta tidak melakukan pembelaan untuk melakukan perusakan atas kebenaran yang ada. Sederhananya jujur dengan dirinya dan orang lain. ${ }^{19}$

Di masa pandemi betapa penting merawat kesehatan mental, sehingga bukan kesehatan fisik saja yang menjadi prioritas utama, akan tetapi aspek tidak terlihat yakni mental untuk memperoleh jiwa yang sehat. Penelitian Kesehatan Mental yang dilakukan Universitas Idonesia dengan Tim Sinergi Mahadata Tanggap Covid-19, merekomendasikan empat hal yakni mencegah krisis kesehatan mental melalui program pengembangan serta akses dukungan berdasarkan data survei. Kemudian memberikan dukungan kesehatan jiwa dan psikososial melalui pengamatan sosial, kesehatan, akses produktifitas maupun edukasi. Melakukan perluasan jangkauan pelayanan kesehatan mental di masyarakat, dan menjamin ketersinambungan layanan kesehatan. ${ }^{20}$

Pandemi Covid-19 memberikan dampak pandak kesehatan mental manusia. Menanggulangi hal ini, quantum ikhlas begitu urgen untuk diterapkan pada setiap orang. Karena quantum ikhlas adalah zona menerima dan bersyukur atas apa pun yang terjadi. Seseorang terganggu kesehatan mentalnya karena kecemasan, kekhawatiran, merasa tidak aman, frustasi, stres, depresi menjadi bagian akibat dari pandemi. Dalam menyelesaikan persoalan kesehatan mental Islam memberikan solusi untuk manusia. Untuk menjangkau zona quantum ikhlas seseorang perlu masuk dengan menanggalkan rasionalitasnya. Dengan ikhlas seseorang dapat menerima dan bersyukur atas pandemi yang belum tahu kapan berakhirnya. Seseorang yang berhasil merawat kesehatan mentalnya akan mengisi kehidupannya dengan kegiatan produktif. Dengan demikian quantum ikhlas untuk kesehatan mental kedudukannya sangat penting bagi manusia

18 Najati, 88.

${ }^{19}$ Najati, 324.

20 Universitas Indonesia, "UI Rekomendasikan Empat Kebijakan Kesehatan Mental Selama Dan Pascapandemi COVID-19,” ui.ac.id, accessed July 10, 2021, https://www.ui.ac.id/ui-rekomendasikan-empat-kebijakan-kesehatan-mental-selama-danpascapandemi-covid-19. 
Role Model yang memiliki kesehatan mental seimbang adalah Rasulullāh. Perilaku yang luhur dan akhlaknya berasal dari Alqur'an. Seimbang yang dimaksud antara material dan spiritual. Meski sebagai seorang nabi Ia menjalani kehidupan selayaknya manusia biasa. Tidak berlebihan dan juga tidak kekurangan. Terkadang puasa dan juga terkadang tidak. Konsep kesehatan mental dalam dirinya tercermin dari Alqur'an berserta hadis yang disinggung dalam nafsu al-mutmainnah. Adalah orang yang memiliki fisik sehat dan kuat, mampu memenuhi kebutuhan pokoknya dengan jalan halal, memenuhi kebutuhan spiritual dengan tauhid, dan melaksanakan segala apa yang diperintah oleh Allah dan menjauhi segala larangan-Nya. Seseorang yang memiliki kepribadian seimbang maka ia akan stabil dan tentu tidak akan menuruti hawa nafsunya. ${ }^{21}$

Seseorang yang sehat mentalnya dalam perspektif Islam pasti ia tidak akan mudah menggerutu, emosi, stres, dan depresi. Apalagi jika ditilik dari beberapa penelitian, ibadah yang diperintahkan oleh Allah senyatanya memberikan kebahagiaan dan orang yang bahagia artinya sehat. Seperti zikir, membaca selawat, salat khusyuk, salat sunnah, puasa, bersedekah, merawat husnudzon, bersikap ikhlas. Itu semua membawa energi positif. Sehingga tidak heran jika ada seseorang yang mengalami gangguan mental perlu diperiksa kembali apakah komponen spiritualnya dan sikapnya telah mencerminkan perintah agama atau tidak.

Damar P Susilaradeya dan Gina Anindyajati sebagai seorang dokter menyebut angka depresi pada masa pandemi mencapai 5\%. Sekitar 5-6 kali lebih besar dibandingkan hasil riset di tahun 2018 dan lebih besar 2-3 kali dari depresi akibat bencana selain pandemi. Mendapati kenyataan inilah, merawat kesehatan mental merupakan kunci produktivitas masyarakat dalam menjalani kehidupan pribadi maupun sosial. Sejumlah korban yang terpapar, baik keluarga, tenaga kesehatan, dan masyarakat umum dapat mengalami gangguan kesehatan mental sehingga berujung pada minimnya kinerja dan produktivitas. Emosi meningkat, kelelahan, ketakutan, stres, kejenuhan, merasa tidak bermakna, terasing menjadi satu. Kasus ini hampir dialami semua kalangan di masyarakat. Dengan begitu meraih kesehatan mental sangat dibutuhkan. ${ }^{22}$

Setidaknya dua defini dari kesehata mental yakni dipahami sebagai kondisi dan pengetahuan. Dikatakan kondisi sebagai wujud dan penyesuaian manusia untuk mencapai kesejahteraan hidup. Sedangkan pengetahuan ditilik

\footnotetext{
${ }^{21}$ Najati, Al-Hadits an-Nabawi Wa 'Ilm an-Nafs, 330-331.

22 Indonesia, "UI Rekomendasikan Empat Kebijakan Kesehatan Mental Selama Dan Pascapandemi COVID-19.”
} 
sebagai ilmu yang bersangkautan dengan kebahagiaan. Meliputi pencegahan, pengobatan, pembinaan, maupun usaha meningkatkan kesehatan mental. ${ }^{23}$

\section{Energi Quantum Ikhlas}

Ikhlas sebuah kata yang begitu mudah untuk diucapkan, tetapi sukar dilakukan. Sebab selama ini selalu berpandangan, hubungan ikhlas dengan sikap lemah. Yang terlihat di dalamnya unsur sabar, diam, tenang, tidak melawan, serta tidak memiliki ambisi. Unsur-unsur ini menjadi alasan khawatir tidak dihargai, tertinggal dalam segalanya, rendahnya kecukupan materi, atau tidak tercapainya keinginan. Tentu eksistensi dugaan-dugaan yang kerap singgah dibenak, tidaklah benar. Sebab keadaannya justru terbalik. Erbe Sentanu menyebut dibalik ikhlas tersembunyi sifat mulia dan positif; cinta, syukur, fokus, serta bahagia. Bahkan sains telah membuktikan keberadaannya, bermodalkan kelembutan ikhlas mampu memberikan energi dahsyat seperti cerdas, pintar, bijak, produktif, powerful, serta sukses dalam segala hal. ${ }^{24}$

Perihal ini sebetulnya semua agama mengajarkan keikhlasan, tidak terkecuali dengan Islam. Beberapa ilmuan pun mengamini atas keberadaannya.

Dan siapakah yang lebih baik agamanya daripada orang yang ikblas menyerabkan dirinya kepada Allah. Sedangkan ia pun mengerjakan kebaikan, Ia mengikuti agama Ibrabim yang lurus. Dan Allah menjadikan Ibrabim sebagai kesayangan-Nya. (QS. AnNisa': 125)

Seseorang yang ikhlas akan dirinya kepada-Nya, menjauhkan segala hal yang membawanya lupa pada sumber segalanya. Ia adalah bagian hamba yang mencintai-Nya. Senada sebuah hadis Qudsi; ikhlas merupakan bagian dari sekian rahasia yang Allah tempatkan di hati hamba yang mecintai-Nya. Oleh karenanya ketika seseorang memilih ikhlas maka bersemayamlah keimanan di dalam sanubari terdalamnya. Sudah barang tentu ketika mencinta penciptanya juga menumbuhkan kasih kepada sekalian semesta. Saling menyayangi dan mengasihi. Mengimplementasikan esensi keikhlasan dalam menghadapi kenyataan hidup. ${ }^{25}$

Ikhlas dalam dunia psikoterapi menjadi sebuah terapi dalam menyembuhkan kesehatan lahir dan batin. Salah satunya digunakan dalam terapi SEFT (Spritual Emotional Freedom Technic) yang diprakarsai oleh Ahmad Faiz Zainuddin. Dalam terapinya ia memadukan berbagai cabang psikoterapi dan psikologi penyembuhan kemudian dintergrasikan dengan spiritual. Komponen ikhlas dalam terapi ini seseorang akan menerima sepenuh hati atas segala yang

${ }^{23}$ Dewi Purnama Sari, "Gangguan Kepribadian Narsistik Dan Implikasinya Terhadap Kesehatan Mental," Bimbingan Dan Konseling Islam 5, no. 1 (2021): 15.

${ }^{24}$ Erbe Sentanu, The Power of Quantum Ikblas For Teens Ilmu Menata Hati Di Masa Muda Untuk Meraih Sukses Di Masa Depan, (Jakarta: Elex Media Komputindo, 2015), ix-x. 211.

${ }_{25}$ Asrifin, Jalan Menuju Ma'rifatullab Dengan Tahapan (7M) (Surabaya: Terbit Terang, 2001), 
terjadi. Tidak mengeluh, tidak complain ketika menghadapi musibah. Karena jika bersikap seperti itu hati akan semakin sakit, sebab tidak menerima kenyataan. Dengan bersikap ikhlas menjadikan seseorang beranggapan sakit yang dialaminya sebagai sarana untuk menyucikan dosa yang kerapkali diperbuat. ${ }^{26}$

Ikhlas juga telah dikaji dengan mengkolaborasikan ilmu pengetahuan di dalamya. Sentanu menyebutnya Quantum Ikhlas adalah sebuah metode pengembangan diri yang mengintegrasikan antara energi sains dan energi ilahi. Basis ilmu pengetahuan terkini, seperti neurosciense, science of the mind, evolutionary biology, chaos theory, and brain science. Kemudian dikorelasikan dengan falsafah keagamaan, sehingga dapat meraih ketentraman. Basisnya tidak menggunakan pikiran dan otak saja, akan tetapi melibatkan perasaan dan jantung. Sebab seseorang yang sukar ikhlas persoalan utamanya ada pada pikiran yang tidak menerima. Selain itu dipilih jantung karena kekuataan yang dimilikinya lima ribu lebih besar dibandingkan kemampuan otak. Ilmu fisika kuantum membuktikan jantung ternyata memiliki otaknya sendiri. ${ }^{27}$

Selama ini kerapkali mendengar positive thinking sebagai tangga untuk mencapai kebahagiaan, sejatinya tidak cukup. Realitanya banyak orang yang mengandalkan pikirannya tetapi masih mencari kebahagiaan dengan melarikan diri pada sesuatu yang negatif. Seperti pejabat yang sudah banyak harta malah melakukan korupsi, anak orang kaya yang sukses masih terjerumus pada obatobatan terlarang. Pada posisi inilah perlu diimbangi dengan positive feeling dalam menjalani hidup. Sentanu menggunakan ikhlas sebagai bagian dari penggabungan antara IQ (intelleigence Quotient, Emotional Quotiont (EQ), dan Spiritual Quationt (SQ) ${ }^{28}$

Quantum sendiri adalah bagian terlembut dan termasuk ke dalam kekuatan alam yang jarang digunakan oleh kebanyakan orang. Realitas kuantum menyebut siapapun bisa mengatur quanta benda untuk mengubahnya menjadi lebih cepat. Dengan begitu, seharusnya yang patut dirubah adalah realitas kuantum sebelum ke fisik. Cara mengaksesnya begitu mudah yakni melalui pikiran, perasaan, dan doa. Ketika menginginkan sesuatu perlu melibatkan usaha keras dan dibersamai dengan bersyukur serta tawakal kepada sumber semesta. Tentu perasaaan syukur dan tawakal ini harus dirasakan di dalam hati, bukan semata-mata terucap di bibir. Sebut saja "ikhlas yang tulus." Karena ketika merasakannya dengan ikhlas dan tulus dari sanubari hati terdalam, seseorang akan menyakini mampu menghadapi apa pun yang ada di hadapannya. Jika demikian maka seseorang akan mudah meraih kesuksesan. ${ }^{29}$

${ }^{26}$ Cintami Fatmawati, "Spiritual Emotional Freedom Technique (SEFT) Sebagai Metode Terapi Sufistik," Madaniyah 8, no. 1 (2018): 88.

27 Sentanu, The Power of Quantum Ikblas For Teens Ilmu Menata Hati Di Masa Muda Untuk Meraih Sukses Di Masa Depan, xvi.

${ }^{28}$ Sentanu, xvii.

${ }^{29}$ Sentanu, 38. 
Dunia quantum berbicara sesuatu yang sangat halus, senada dengan pembahasan energi alam bahwa sadar. Sekitar 88\% dalam kehidupan manusia terdiri dari alam bawah sadar. Adji Syuhada menyebutkan alam bawah sadar memiliki energi yang begitu luar biasa. Itulah mengap manfaatnya bukan hanya untuk diri sendiri tetapi orang lain. Misalnya menggunakan praktik penyembuhan dengan doa jarak jauh, dan sebangsanaya. Dengan mengaktifkan alam bawah sadar dapat membawa spiritual meningkat dan hubungan antara horizontal serta vertkcal pun berjalan simultan. ${ }^{30}$

Itulah mengapa perasaan adalah dasar dari pikiran, tindakan, kebiasaan, karakter, hingga nasib. Bisa dianalogikan quanta adalah bahan dasarnya dalam mengubah sesuatu, perasaaan menjadi kontrol segala hal. Semakin halus dan dalam maka energi yang dihasilkan semakin besar. Begitupun ketika quantum ikhlas bekerja, di kala seseorang merasa benar-benar ikhlas pada saat itulah posisi perasaan dan doa, mengaktifkan quanta dan menarik quanta yang diinginkan. Melalui kinerja kuantum yang tidak kasat mata disanalah campur tangan kekuatan Tuhan bekerja. ${ }^{31}$

Lā haula wa lā quwwata illā billāhi al 'aliyyi al 'adzīmi

Tiada daya dan upaya melainkan pertolongan Allah

Sikap ikhlas berarti menerima segala ketentuan yang telah diberikan oleh Allah. Karena ketika menolak keadaan berarti tidak berdamai dan ini akan menggangu kesehatan mental manusia. Bahkan hingga menimbulkan psikosomatis seperti insomnia, dan gangguan fisik lainnya. Di saat seseorang mendapatkan tantangan sebaiknya beralih pada zona ikhlas.Itulah mengapa harus menggunakan positive feeling dan nyaman untuk masuk ke zona ini. ${ }^{32}$

Mendapatkan hati yang ikhlas tidaklah mudah, butuh usaha terus menerus. Namun bukan berarti tidak bisa. Setidaknya ada beberapa tahapan yang harus dilakukan seseorang dalam proses internalisasi ikhlas seperti; menuntut ilmu yang bermanfaat, menguatkan spiritual kedekatan dengan Tuhan, berteman dengan orang-orang saleh, bermunajat dan berdoa kepada Tuhan. Itu semua bisa didapatkan karena keikhlasan adalah bagian dari rangkaian istikamah dan komitmen. ${ }^{33}$

${ }^{30}$ Adji S Syuhada, Mengunduh Energi Allah Terapi Energi Kelistrikan Otak Lewat Ibadah (Jakarta: Suluk, 2014), 39.

${ }^{31}$ Sentanu, The Power of Quantum Ikblas For Teens Ilmu Menata Hati Di Masa Muda Untuk Meraih Sukeses Di Masa Depan, 30-34.

32 Erbe Sentanu, Zona Ikblas \#Reborn Aplikasi Teknologi Kekuatan Hati (Jakarta: Elex Media Komputindo, 2016), 27.

${ }^{33}$ Khairunnas Rajab, Psikoterapi Islam (Jakarta: Bumi Aksara, 2019), 347. 


\section{Quantum Ikhlas untuk Kesehatan Mental di Tengah Pandemi}

Pandemi telah memberikan dampak pada kesehatan mental, setidaknya disebabkan beberapa faktor ini. Pertama, mengalami terisolasi, tindakan ini dilakukan agar terhindar dari penularan virus Covid-19. Akan tetapi sebagian orang mengalami kekhawatiran dan ketakutan tertular. Kedua, kesulitan mengakses layanan kesehatan mental. Ketiga, rencana yang dibatalkan dan perubahan rutinitas. Keempat, ketidakpstian kapan berakhirnya Covid. Kelima, banyaknya pemberitaan mengenai Covid-19, sehingga tidak jarang membawa informasi hoax. Kelima inilah memberikan sumbangsih terbesar pada rendahnya kesehatan mental masyarakat global. ${ }^{34}$

Pada tahap kecemasan, kekhawatiran, depresi hingga mengganggu kesehatan mental manusia diperlukan usaha untuk ikhlas dalam rangka menerima keadaan. Tahap-tahap itulah yang kerapkali menghantui masyarakat global, khususnya di Indonesia. Meminjam term Viktor Emil Frankl Meaningfull Life. Dengan menekankan pada rohani dan pengobatan pasien dalam menghadapi kemurungan, ketegangan, tekanan mental, dam kecemasan. ${ }^{35}$ Semua itu memiliki keterhubungan dalam kesehatan mental di tengah pandemi Covid 19. Di tengah mengalami krisis akibat pandemi seseorang membutuhkan makna dalam memandang keadaan. Karena dengannya dapat mengatasi stres, trauma, dan kesulitan. ${ }^{36}$

Selama pandemi banyak orang yang tidak menerima dengan keadaan, karena tidak menemukan maknanya. Alih-alih terbukti merasa kecewa, khawatir dengan keuangan, sedih, merasa tidak aman, marah dengan keadaan. ${ }^{37}$ Ketika mendengar banyak sanak keluarga terserang virus Covid-19 menyalahkan menjadi sebuah pilihan.Pada tahap kecemasan hingga mengganggu kesehatan mental manusia diperlukan usaha untuk ikhlas dalam rangka menerima keadaan. Tahap-tahap itulah yang kerapkali menghantui masyarakat global, khususnya di Indonesia. Meminjam term Viktor Emil Frankl Meaningfull Life. Dengan menekankan pada rohani dan pengobatan pasien dalam menghadapi

34 Alexandra Burton et al., "Impact of the COVID-19 Pandemic on the Mental Health and Well-Being of Adults with Mental Health Conditions in the UK: A Qualitative Interview Study Adults with Mental Health Conditions in the UK: A Qualitative Interview Study," Journal of Mental Health 0, no. 0 (2021): 3-4, https://doi.org/10.1080/09638237.2021.1952953.

35 Zulkarnain and Siti Fatimah, "Kesehatan Mental Dan Kebahagiaan: Tinjauan Psikologi Islam,” Mawa'iz: Jurnal Dakwah Dan Pengembangan Sosial Kemanusiaan 10, no. 1 (2019): 22.

${ }^{36}$ Lea Waters et al., "Positive Psychology in a Pandemic: Buffering, Bolstering, and Building Mental Health," Journal of Positive Psychology 00, no. 00 (2021): 4, https://doi.org/10.1080/17439760.2021.1871945.

${ }^{37}$ Jessica A. Jonikas et al., "The Impact of the COVID-19 Pandemic on the Mental Health and Daily Life of Adults with Behavioral Health Disorders," Translational Behavioral Medicine 11, no. 5 (2021): 1166, https://doi.org/10.1093/tbm/ibab013. 
kemurungan, ketegangan, tekanan mental, dam kecemasan. ${ }^{38}$ Viktor Emil Frankl mengatakan sejatinya dibalik penderitaan ada makna yang bisa diambil. Kedudukan makna ini tidak bisa dipisahkan dari kehidupan manusia. Artinya penderitaan tidak menjadi boomerang untuk mendapatkan hikmah atau pelajaran. Baginya tanpa ada penderitaan dan kematian hidup terasa tidak sempurna. ${ }^{39}$

Senada dengan Quraish Shihab melihat adanya Covid 19, banyak pekerja di rumahkan terdapat hikmah yang bisa diambil pelajarannya. Kematian karena Covid-19 terus meningkat. Akan tetapi kembali lagi kematian adalah keniscayaan yang pasti. Islam sebagai agama rahmat sejatinya telah memberikan solusi kepada hambanya di saat mendapatkan tantangan di dunia ini. Alqur'an sebagai pedoman hidup yang selalu relevan dalam setiap zaman. Khairunnas Rajab seorang profesor psikoterapi Islam mengatakan sebagai agama bermuatan nilai spiritual tinggi, Islam mampu menyelesaikan masalah psikologis manusia. Dengan menggunakan dimensi Islam seperti iman, ibadah, muamalah, akhlak, dan tasawuf dapat mewujudkan kesehatan mental. Seperti menggunakan quantum ikhlas. Hati yang tulus menentukan esensi manusia. Dalam mencapainya perlu melakukan berbagai latihan dengan mendekatkan diri kepada Allah. Saat hati bersih dan ikhlas, wabah seperti Covid-19 kemudian datang melanda, tidak menjadikan diri seseorang cemas, khawatir, dan mengganggu kesehatan mental. ${ }^{40}$

Dengan menerapkan quantum ikhlas seseorang akan merasa tenang, bersyukur, menerima, pasrah kepada Allah dan ini akan melahirkan makna hidup. Sebuah makna yang menjadikan seseorang merasa bahagia atas hidupnya dan merasa berarti. Sehingga menggunakan segala kemampuannya untuk tetap produktif di tengah keterbatasan adanya Covid-19. Berusaha menyesuaikan dengan keadaan, bukan malah menolak keadaan. Meski keadaan lebih banyak di rumah, belajar, bekerja, hingga soal diisolasi di ruangan sendirian, seseorang yang penuh kesehatan mentalnya akan menerimanya dengan ikhlas dan lapang dada. Selalu beranggapan ada hikmah dibalik sesuatu. ${ }^{41}$

Dengan memanfaatkan quantum ikhlas sudah termasuk ke dalam bagian ikhtiar dalam menembus rasionalitas untuk masuk ke zona ikhlas yang dipenuhi dengan kepasrahan. Sembari menyerahkan segala rencana dan niat kepada Maha Segalanya. Selaras dengan fenomena selama pandemi Covid 19, betapa banyak keadaan dan kenyataan yang tidak pernah terpikir sebelumnya. ${ }^{42}$

38 Zulkarnain and Fatimah, "Kesehatan Mental Dan Kebahagiaan: Tinjauan Psikologi Islam," 22.

${ }^{39}$ Viktor Emil Frankl, Man's Search for Meaning (Jakarta: Noura, 2018), 97.

${ }^{40}$ Rajab, Psikoterapi Islam, 117.

${ }^{41}$ Zulkarnain and Fatimah, "Kesehatan Mental Dan Kebahagiaan: Tinjauan Psikologi Islam," 28.

42 Sentanu, Zona Ikblas \#Reborn Aplikasi Teknologi Kekuatan Hati, 28. 


\section{Penutup}

Pandemi Covid-19 memberikan dampak pada kesehatan mental manusia. Menanggulangi hal ini, quantum ikhlas begitu urgen untuk diterapkan pada setiap orang. Karena quantum ikhlas adalah zona menerima dan bersyukur atas apa pun yang terjadi. Seseorang terganggu kesehatan mentalnya karena kecemasan, kekhawatiran, merasa tidak aman, frustasi, stres, depresi menjadi bagian akibat dari pandemi. Dalam menyelesaikan persoalan kesehatan mental Islam memberikan solusi untuk manusia. Untuk menjangkau zona quantum ikhlas seseorang perlu masuk dengan menanggalkan rasionalitasnya. Dengan ikhlas seseorang dapat menerima dan bersyukur atas pandemi yang belum tahu kapan berakhirnya. Seseorang yang berhasil merawat kesehatan mentalnya akan mengisi kehidupannya dengan kegiatan produktif. Dengan demikian quantum ikhlas untuk kesehatan mental kedudukannya sangat penting.

\section{Daftar Pustaka}

Adji S Syuhada. Mengunduh Energi Allah Terapi Energi Kelistrikan Otak Lewat Ibadah. Jakarta: Suluk, 2014.

Asrifin. Jalan Menuju Ma'rifatullab Dengan Tahapan (7M). Surabaya: Terbit Terang, 2001.

Ayub Rustiani. "Data Riset: Kesehatan Mental Mahasiswa Saat Pandemi \& Kuliah Online." tirto.id, 2021. https:/ / tirto.id/data-riset-kesehatan-mentalmahasiswa-saat-pandemi-kuliah-online-gaEc.

Burton, Alexandra, Alison Mckinlay, Henry Aughterson, Daisy Fancourt, Alexandra Burton, Alison Mckinlay, Henry Aughterson, et al. "Impact of the COVID-19 Pandemic on the Mental Health and Well-Being of Adults with Mental Health Conditions in the UK: A Qualitative Interview Study Adults with Mental Health Conditions in the UK: A Qualitative Interview Study." Journal of Mental Health 0, no. 0 (2021): 1-8. https://doi.org/10.1080/09638237.2021.1952953.

Daradjat, Zakiah. Kesehatan Mental. Jakarta: Haji Masagung, 1990.

Darmawan, Dadang, Deni Miharja, Roro Sri Rejeki Waluyajati, and Erni Isnaeniah. "Sikap Keberagamaan Masyarakat Menghadapi Wabah COVID19." Religious: Jurnal Studi Agama-Agama Dan Lintas Budaya 4, no. 2 (2020): 115-24. https://doi.org/10.15575/rjsalb.v4i2.8596.

Fatmawati, CIntami. "Spiritual Emotional Freedom Technique (SEFT) Sebagai Metode Terapi Sufistik." Madaniyah 8, no. 1 (2018): 75-91.

Frankl, Viktor Emil. Man's Search for Meaning. Jakarta: Noura, 2018.

Ilpaj, Salma Matla, and Nunung Nurwati. "Analisis Pengaruh Tingkat Kematian 
Akibat COVID-19 Terhadap Kesehatan Mental Masyarakat Di Indonesia." Focus: Jurnal Pekerjaan 2020. https://doi.org/10.24198/focus.v3i1.28123.

Indonesia, Universitas. "UI Rekomendasikan Empat Kebijakan Kesehatan Mental Selama Dan Pascapandemi COVID-19." ui.ac.id. Accessed July 10, 2021. https://www.ui.ac.id/ui-rekomendasikan-empat-kebijakankesehatan-mental-selama-dan-pascapandemi-covid-19.

Iqbal, Muhammad, and Lutfiyah Rizqulloh. "Deteksi Dini Kesehatan Mental Akibat Pandemi Covid-19 Pada Unnes Sex Care Community Melalui Metode Self Reporting Questionnaire." Praxis 3, no. 1 (2020): 20. https://doi.org/10.24167/praxis.v3i1.2730.

Jonikas, Jessica A., Judith A. Cook, Margaret Swarbrick, Patricia Nemec, Pamela J. Steigman, Katherine A. Boss, and George H. Brice. "The Impact of the COVID-19 Pandemic on the Mental Health and Daily Life of Adults with Behavioral Health Disorders." Translational Behavioral Medicine 11, no. 5 (2021): 1162-71. https://doi.org/10.1093/tbm/ibab013.

Kementerian Kesehatan. "Sehat Jiwa." kemkes.go.id. Accessed July 9, 2021. https://promkes.kemkes.go.id/content/?p=7385.

Kementerian Pendidikan dan Kebudayaan Indonesia. "KBBI V." Badan Pengembangan Bahasa dan Perbukuan, 2020.

Mustarsyida, Ainun, and Erni Munastiwi. "Problematika Orang Tua Dalam Mendampingi Anak Pada Pembelajaran Era Pandemi Covid-19." Islamic Counseling: Jurnal Bimbingan Dan Konseling Islam 5, no. 1 (2021): 1-14. http://journal.iaincurup.ac.id/index.php/JBK.

Nadya. "Konsep Sehat Dan Sakit." uin-alauddin.ac.id, 2013. https://uinalauddin.ac.id/tulisan/detail/konsep-sehat-dan-sakit.

Najati, Muhammad 'Utsman. Al-Hadits an-Nabawi Wa 'Ilm an-Nafs. Bandung: Pustaka Hidayah, 2005.

Rajab, Khairunnas. Psikoterapi Islam. Jakarta: Bumi Aksara, 2019.

Retia Kartika Dewi. "Hari Kesehatan Mental Sedunia: Apa Itu Kesehatan Mental Dan Bagaimana Cara Menjaganya." kompas.com. Accessed July 10, 2021. https://www.kompas.com/tren/read/2020/10/10/171200265/harikesehatan-mental-sedunia-apa-itu-kesehatan-mental-dan-cara-menjaganya.

Rizky Claravita. “Terapi Realitas Berbasis Nilai-Nilai Ikhlas Untuk Mengurangi Stress Dan Kecemasan Akan Gagalnya Resepsi Karena Pandemi COVID19 Pada Pasangan Calon Pengantin Di Kelurahan Morokrembangan Surabaya." UIN Sunan Ampel Surabaya, 2020.

Sari, Dewi Purnama, Institut Agama, Islam Negeri, and Iain Curup. "Gangguan 
Kepribadian Narsistik Dan Implikasinya Terhadap Kesehatan Mental." Bimbingan Dan Konseling Islam 5, no. 1 (2021): 93-114.

Sentanu, Erbe. The Power of Quantum Ikblas For Teens Imu Menata Hati Di Masa Muda Untuk. Meraih Sukses Di Masa Depan. Ke-1. Jakarta: Elex Media Komputindo, 2015.

- Zona Ikblas \#Reborn Aplikasi Teknologi Kekuatan Hati. Jakarta: Elex Media Komputindo, 2016.

Tri Purna Jaya. "Sederet Kasus Warga Tolak Pemakaman Jenazah Pasien Covid19 Di Berbagai Daerah." kompas.com, 2020. https://regional.kompas.com/read/2020/04/01/05200021/sederet-kasuswarga-tolak-pemakaman-jenazah-pasien-covid-19-di-berbagai.

Waters, Lea, Sara B. Algoe, Jane Dutton, Robert Emmons, Barbara L. Fredrickson, Emily Heaphy, Judith T. Moskowitz, et al. "Positive Psychology in a Pandemic: Buffering, Bolstering, and Building Mental Health." Journal of Positive Psychology 00, no. 00 (2021): 1-21. https://doi.org/10.1080/17439760.2021.1871945.

Winurini, Sulis. "Permasalahan Kesehatan Mental Akibat Pandemi COVID-19." Info Singkat: Kajian Singkat Terbadap Isu Aktual Dan Strategis, 2020.

Zulkarnain, and Siti Fatimah. "Kesehatan Mental Dan Kebahagiaan: Tinjauan Psikologi Islam." Mawa'iæ: Jumal Dakwah Dan Pengembangan Sosial Kemanusiaan 10, no. 1 (2019): 18-38. 
222 | Islamic Counseling: Jurnal Bimbingan dan Konseling Islam, Vol. 5, No. 2, 2021 